\title{
New data on Calomera panormitana panormitana (Ragusa, 1906) in Sicily (Coleoptera Cicindelidae)
}

\author{
Ignazio Sparacio' \& Salvatore Surdo²
}

'Via Principe di Paternò 3, 90144 Palermo, Italy; e-mail: edizionidanaus@gmail.com

${ }^{2}$ Dipartimento di Scienze agrarie, alimentari e forestali, viale delle Scienze, Edificio 4, 90128 Palermo, Italy; e-mail: salvatore.surdo@unipa.it Orcid: 0000-0002-0300-837X

\begin{abstract}
Calomera panormitana panormitana (Ragusa, 1906) (Coleoptera Cicindelidae) is an endemic species of Sicily, of remarkable biogeographic and ecological importance. It belongs to a small group of species of eastern Mediterranean distribution and it is peculiar for living on the low rocky coasts, near the sea. In this paper we provide new and summarized data on the presence of this species in Sicily. We examined its habitat, ecology and phenology in detail, and we provide useful elements for a better protection. In particular, the presence of this species also in some small islands, located at a short distance from the coast, highlights the presence of important refuge areas to be protected and promoted.
\end{abstract}

KEY WORDS Coleoptera; Mediterranean; ecology; biogeography; bioindicators; small islands.

Received 29.10.2020; accepted 22.11.2020; published online 30.12.2021

\section{INTRODUCTION}

Calomera panormitana (Ragusa, 1906) (Coleoptera Cicindelidae) is a species with eastern Mediterranean range present with the nominal subspecies in Sicily, with the subspecies cypricola (Mandl, 1981) in Cyprus and Rhodes and with the subspecies cretensis Romano et Sparacio, 2018 in Crete (Romano \& Sparacio, 2018). Calomera aphrodisia (Baudi di Selve, 1864), a related species, is present in the coasts of Turkey, Syria and Lebanon.In recent years, there have been differing interpretations both on the taxonomic role of these populations, especially in relation to their original ranges, and on the correct attribution of the name "panormitana" for the Sicilian populations as summarized by Romano \& Sparacio (2018). The latter designate the lectotype of Calomera panormitana panormitana and the neotype of $C$. littoralis nemoralis var. lugens Dejean, 1831.
Described by Ragusa (1906) for Mondello near Palermo (see also Ragusa, 1882, 1884, 1887, 1904), C. panormitana panormitana was mentioned in the following years for a few other locations: Vitale, 1912 and 1913 (Mondello), 1927 (Bauso); Ragusa, 1921 (Balestrate); Aliquò \& Romano, 1976 (Mondello, Isola delle Femmine, Sferracavallo, Balestrate, Foci F. Simeto).

Cassola $(1982,1983)$ re-evaluates the known locations and adds others on the basis of personal observations: Vendicari, San Vito Lo Capo, Macari, Birgi (Torre San Teodoro), Penisola della Maddalena (Faro Castelluccio Siracusa). This allows to assign to this species a presence in almost all of Sicily but with small populations and limited to the rocky coasts. Arnone (1994: Mondello, Porticello, Isola delle Femmine), Sparacio (1994), Aliquò \& Castelli (1991), Lisa (2002: Fontane Bianche Siracusa) and Romano \& Sparacio (2018: San Vito Lo Capo, Cinisi, Carini Torre Pozzillo, Sferraca- 
vallo Punta Matese and Barcarello, Isola delle Femmine Punta della Catena, Castelluzzo, Golfo di Cofano) provide additional locations inhabited by this species.

From a biological point of view, Cassola (1983), by studying Sicilian populations, provides important information on the habits of this species that lives in the particular environment of rocky coasts. Here, it feeds on small invertebrates such as crustaceans of the genus Ligia Fabricius, 1798 and gastropod molluscs of the genera Littorina Férussac, 1822 and Gibbula Risso, 1826 that it seeks in the summer months.

In the last years, the presence of Calomera panormitana panormitana in Sicily, object of the present work, has been monitored to evaluate its current distribution, population size and conservation level.

\section{MATERIAL AND METHODS}

Scientific researches were conducted during the hottest hours of the day in June, July, and August of the years 2019, 2020, and 2021. Calomera panormitana panormitana was searched by sight in the typical environments in which it lives: the low rocky coasts that touch the sea.

The locations known in the bibliography were double-checked and other locations with suitable environments for the presence of this species were investigated.

The researches we carried out have been developed mainly in the north-western Sicily and, to a lesser extent, in south-eastern Sicily, where most of the locations inhabited by this species are present. All the observations were noted down and photos of the environments surveyed and of this species in the wild were taken (Canon Eos 100D camera macro $100 \mathrm{~mm}$ ). Study material is stored in the $\mathrm{Ig}$ nazio Sparacio collection of Palermo (Italy).

\section{RESULTS}

The results of the research carried out in Sicily on the presence of $C$. panormitana panormitana (Figs. 1-3) are summarized in Fig. 4, where the data obtained from the cited bibliography (confirmed and not confirmed) are also summarized.

\section{Coasts near Palermo}

In the littoral zone to the west of the city of Palermo, C. panormitana panormitana has definitively disappeared from the typical location of Mondello, a naturalistic biotope that has since the early 1900s been destroyed (Lapiana \& Sparacio, 2008). Some data on this locality, up to 1928 , can be found in the collection R. Alliata of Palermo and cited by Aliquò \& Romano (1975) and Arnone (1994). Nowadays, we have found this species in a few specimens in the cliffs of Addaura and Capo Gallo, near Mondello.

Other small isolated populations of C. panormitana panormitana live along the coastline from Barcarello-Sferracavallo (Fig. 5), in the Municipality of Isola delle Femmine, Villagrazia di Carini (Torre Pozzillo, Torre della Tonnara dell'Ursa) and Cinisi (Magaggiari-Torre Mulinazzo).

\section{Isola delle Femmine}

Isola delle Femmine is located to the northwest of Sicily ( $\left.38^{\circ} 12^{\prime} 36^{\prime \prime N} 13^{\circ} 14^{\prime} 10^{\prime \prime} \mathrm{E}\right)$, near Palermo, along a stretch of coast between Capo Gallo and Punta Raisi, in the Gulf of Carini. It belongs to the Municipality of Isola delle Femmine that adjoins Palermo (Sferracavallo) to the East and Capaci to the west.

The islet covers an area of about 14 hectares and has an almost oval shape. Its major axis, NW-SE oriented, is $575 \mathrm{~m}$ long, its maximum width $325 \mathrm{~m}$, and the highest point reaches $36.80 \mathrm{~m}$ asl where an ancient tower was built.

Isola delle Femmine Nature Reserve was established under decree $\mathrm{n}^{\circ}$ 584, 01/09/1997 (Suppl. Ord. G.U.R.S. ${ }^{\circ} 3$ 17/01/1998) by the Region of Sicily and managed by LIPU/Birdlife Italia (Di Dio, 2011).

This island is a part of the regional protected areas belonging to Nature 2000 network under European Directives 79/409/CEE (on the conservation of wild birds) and 92/43/CEE (on the conservation of natural habitats and of wild fauna and flora) as Site of Community Importance with code ITA020005 (Isola delle Femmine). Afterwards, on the island was established a geosite with decree D. Ass. R. Sicilia 29/08/2017, n. 283/Gab.

The population of Calomera panormitana panormitana that we observed at Isola delle Fem- 


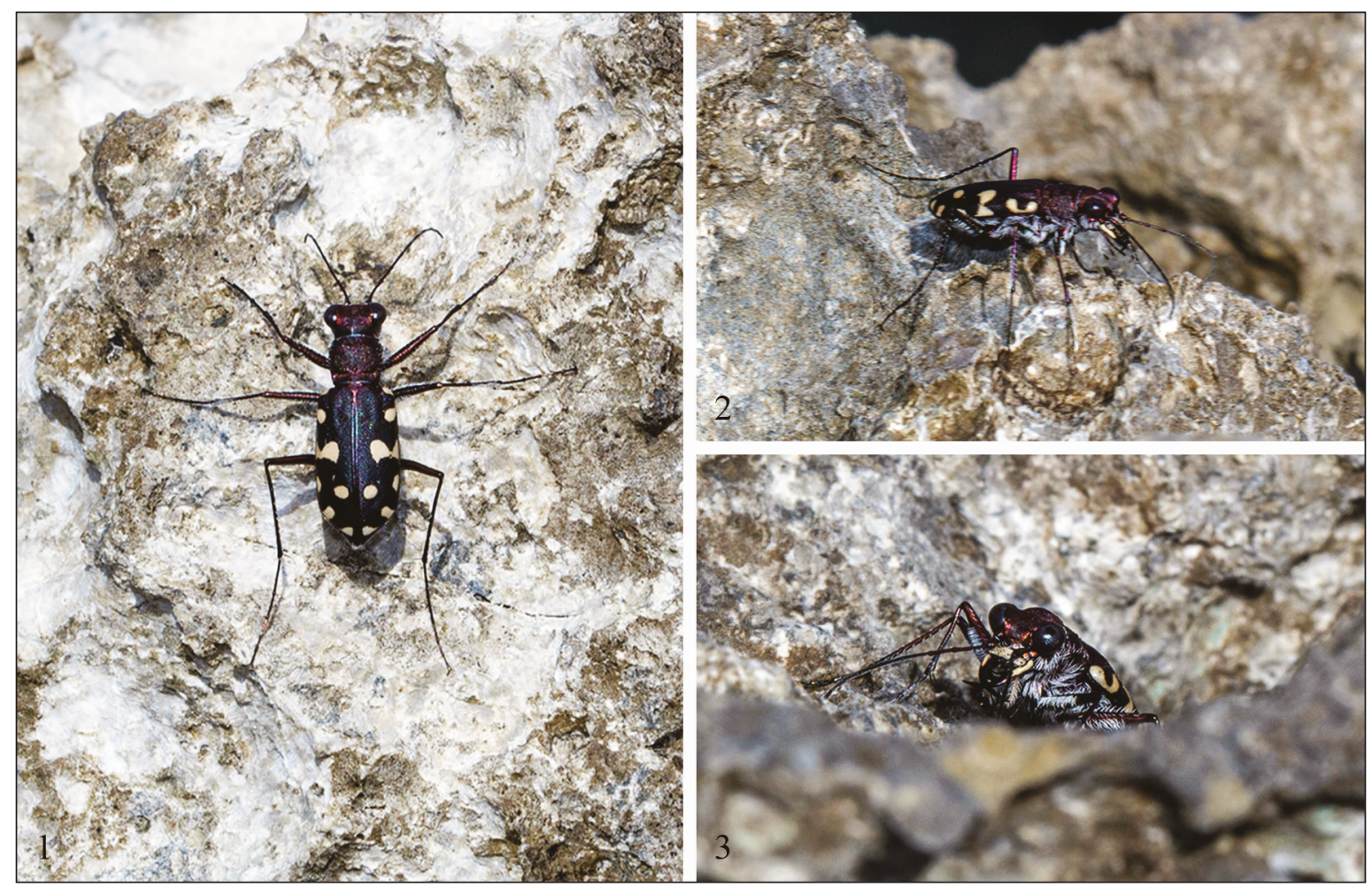

Figure 2. Calomera panormitana panormitana from Isola delle Femmine (Palermo).

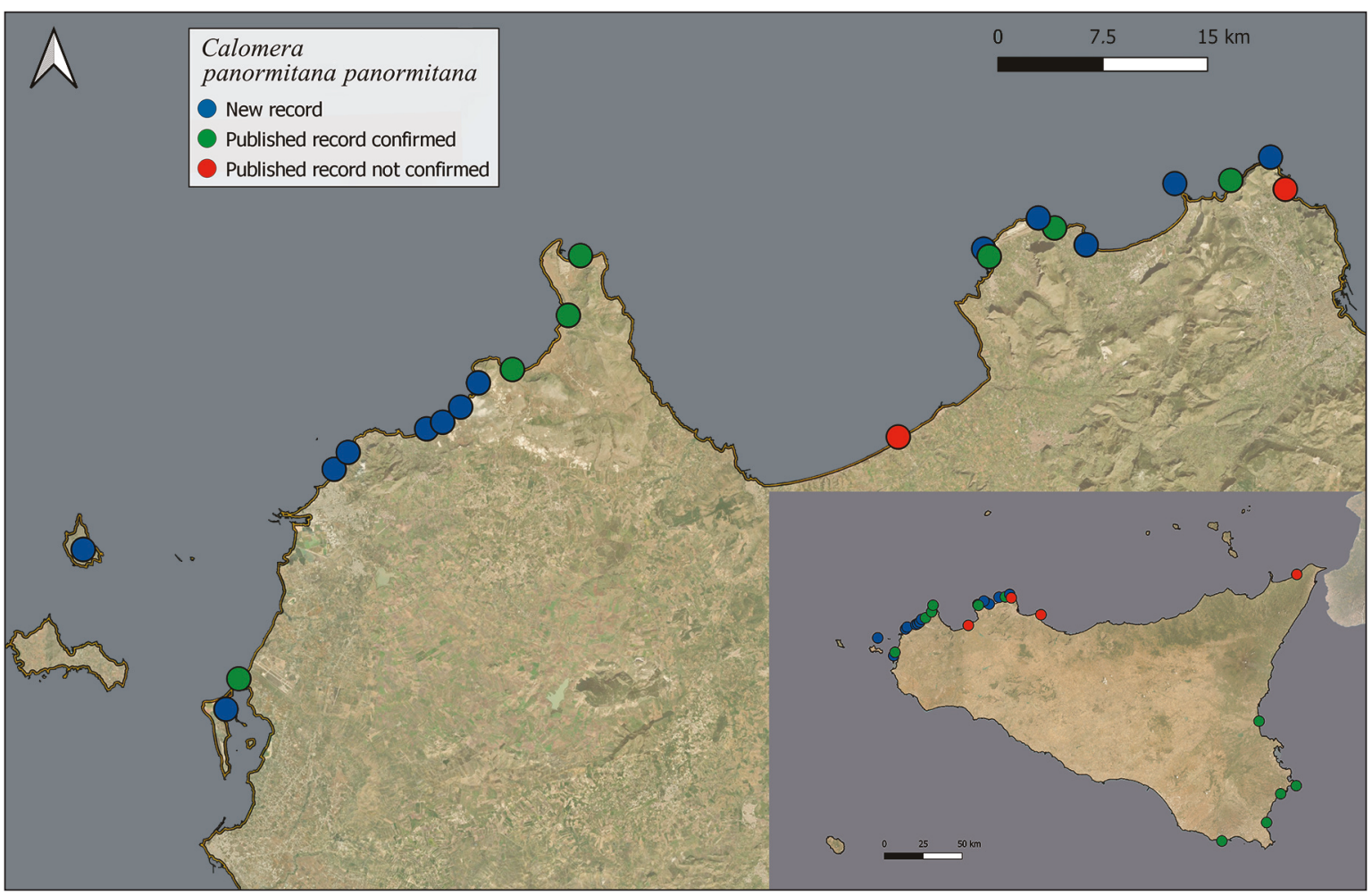

Figure 3. Results of the research carried out in Sicily on the presence of C. panormitana panormitana. 
mine on 12.VII.2021 (Figs. 1-3) is concentrated in a greater number of specimens only in some points of the cliff, while single specimens were observed on the whole perimeter (about $1.74 \mathrm{~km}$ ) of the island.

Calomera panormitana panormitana was not known for this location and, also considering the extension of the suitable environments, Isola delle Femmine could represent an important refuge for this species.

\section{Coasts near Trapani}

Calomera panormitana panormitana has been observed in several stretches of rocky coastline from Tonnara di San Cusumano (Erice) to Monte Cofano (Custonaci) with populations well distributed between Lido Valderice and Monte Cofano (Fig. 5) but separated from the populations of the other stations (Tonnara San Cusumano, Pizzolungo) which are themselves separated from each other. All these locations are new and previously unknown but we believe this is not due to an expansion of the range but because of a greater research effort.

The presence of this species in the coast between the beach of San Vito Lo Capo and the Gulf of Cofano remains confirmed.

In the surroundings of Trapani, despite of several researches carried out in June and July 2020 and 2021, C. panormitana was not found in the following locations: Capo Boeo (Marsala); Punta Sibiliana (Petrosino); the waterfront for about 2.5 $\mathrm{km}$ after the Arena River to the east; Capo Granitola (Mazara del Vallo), stretches of coast that apparently present suitable conditions for the species. Only Myriochila melancholica has been found in Petrosino.

A few hours search carried out on 3.VIII.2021 in Favignana and limited to a short stretch of coast (800 meters), potentially suitable for the species, was unsuccessful.

\section{Isola Lunga of the Stagnone di Marsala}

Isola Lunga (or "Isola Grande") is the largest island of the archipelago of Stagnone di Marsala. It is located in front of the entire coastal lagoon from North to South for about $6.5 \mathrm{~km}$ as a kind of natural dam. Flat and very elongated along its North-South axis, Isola Lunga originates from the artificial union of other small islands (Donato, 2013). Its surface is about 445 hectares, of which 258 are occupied by active salt pans, abandoned or still used. The island falls within the zone A of the protected area of Stagnone Islands Nature Reserve of Marsala established by D.A. $\mathrm{n}^{\circ}$ 215/4.7.1984 (G.U.R.S. $\mathrm{n}^{\circ}$ 34/11.8.1984).

The Oriented Regional Natural Reserve protects an area of 2.012 hectares approximately, with marine lagoon, islands and coastal salt marshes partly still active. It is located in the Municipality of Marsala (Trapani). The reserve is composed by four islands (zone A) and the coastal strip that includes the Genna salt pans, the Ettore salt pans, the Infersa salt pans and the S. Teodoro salt pans (zone B).

On 1.VII.2019, six individuals of C. panormitana panormitana were observed in a small rocky stretch located in the northern portion of Isola Lunga. This is the only rocky stretch, about a hundred meters in length, present on the Island, which has a total perimeter of $17 \mathrm{~km}$. This location is about $380 \mathrm{~m}$ from the Sicilian promontory of Capo San Teodoro.

This species was already known in Capo San Teodoro (Cassola, 1983) and in this area there is only a short stretch of rocky coast about $250 \mathrm{~m}$ long. This small population from Capo San Teodoro, moreover, is almost $16 \mathrm{~km}$ away from the closest ones (Tonnara San Cusumano, Erice) in a beeline. Calomera panormitana was observed at Capo San Teodoro on 1.VII.2019 too.

In addition to C. panormitana, three other $\mathrm{Ci}$ cindelidae species were found on Isola Lunga: Cephalota litorea goudoti, Cephalota circumdata imperialis (Surdo, 2016) and Myriochila melancholica. Cephalota circumdata imperialis was also seen again on 31.V.2019 and on 10.VI.2019 again, but only a single individual this time, confirming the rarefaction of the species.

\section{Levanzo}

The Protected Marine Area of the Aegadian Islands, that extends on this territory too, was established by Ministerial Decree of December 27, 1991, and covers 53,992 hectares divided into four areas with different levels of protection and with different access options and limitations. The island of Levanzo falls almost entirely within zone $\mathrm{C}$ and only the western coastal zone is part 


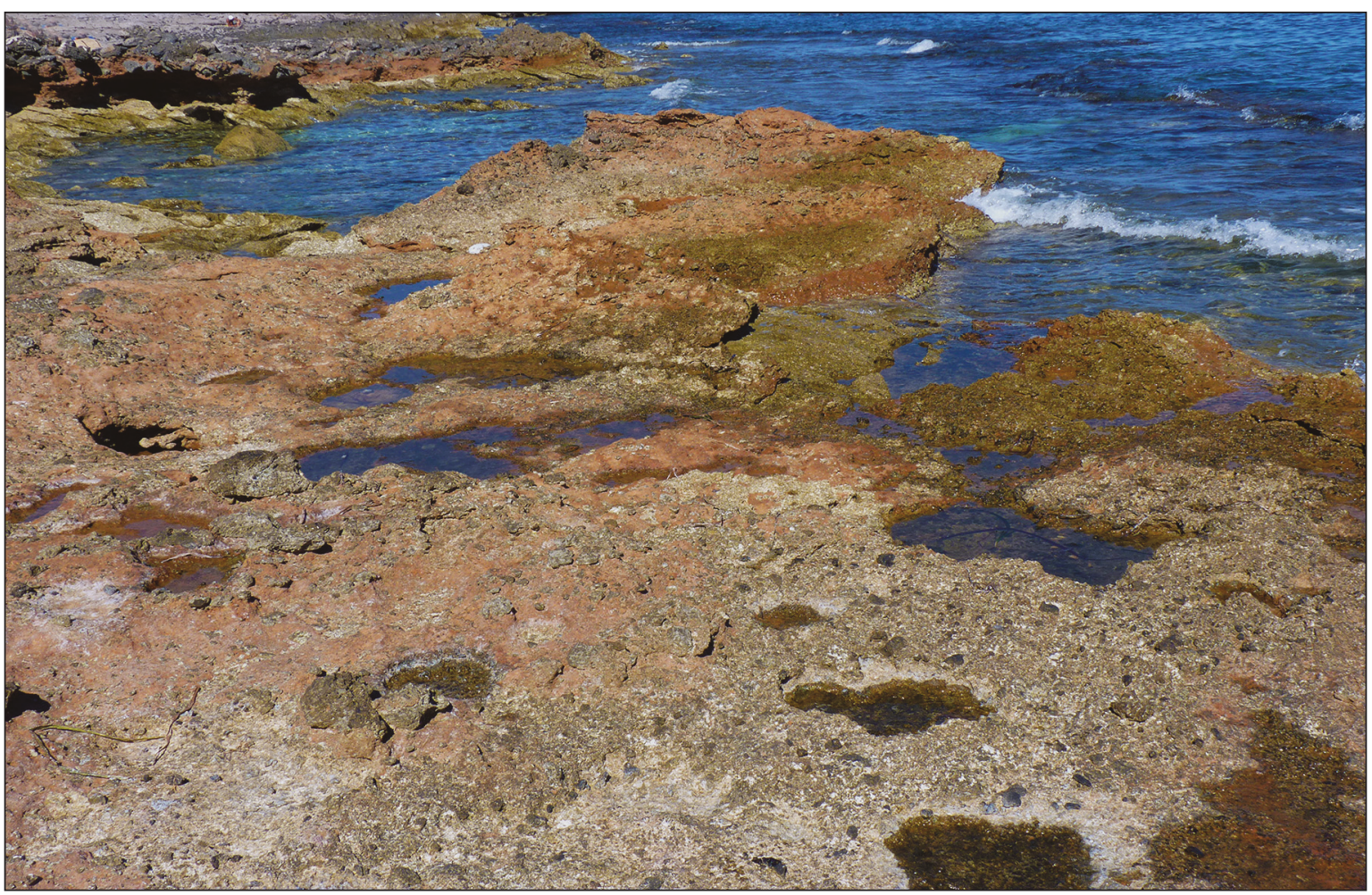

Figure 5. Habitat of Calomera panormitana panormitana near Sferracavallo (Palermo).

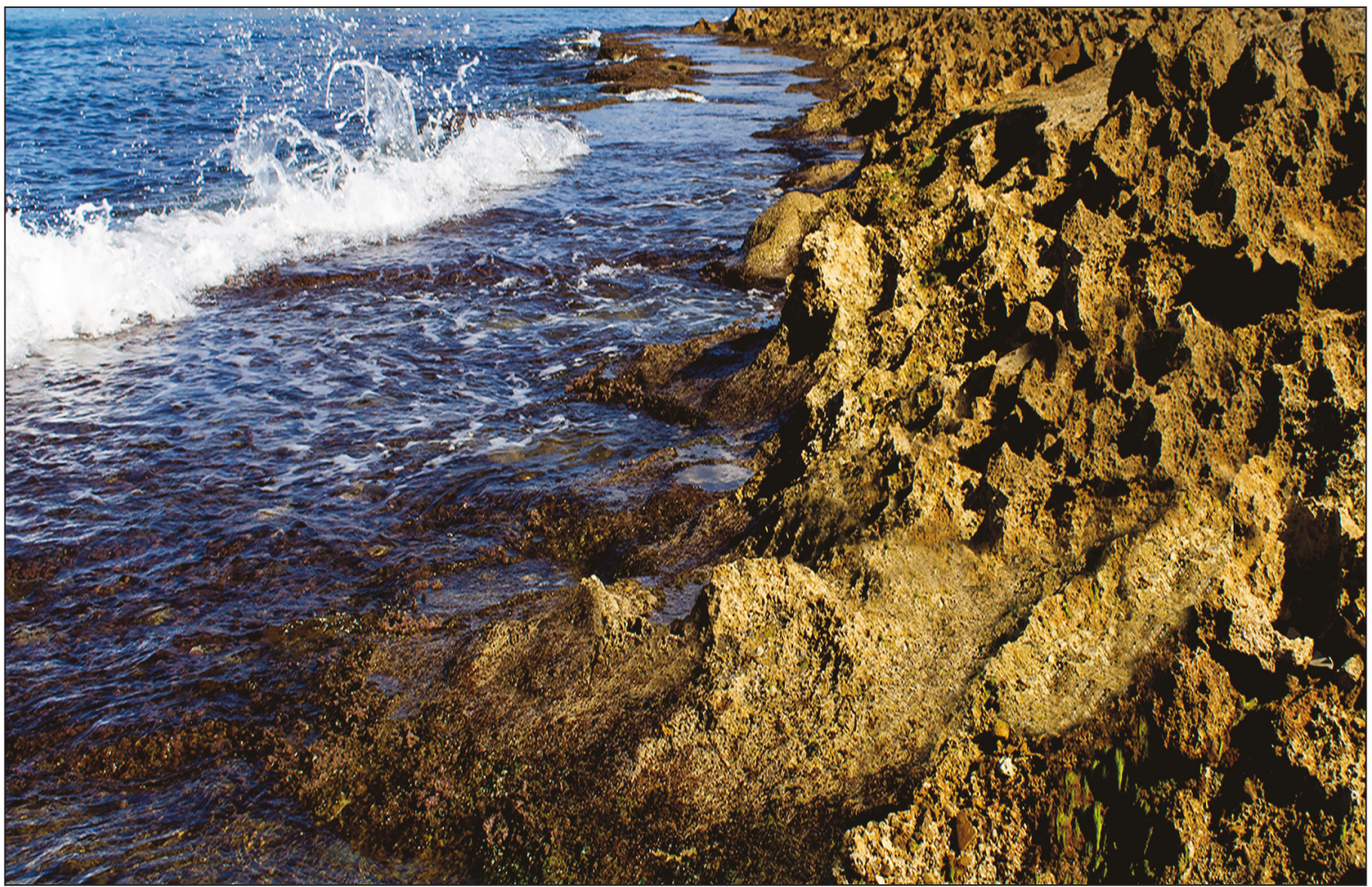

Figure 6. Protective effect of the trottoir in the habitat of Calomera panormitana panormitana near Trapani. 
of zone B which guarantees greater protection of the coast.

In Levanzo, six specimens of $C$. panormitana panormitana were observed on 17.VII.2021 and another five individuals on 2.VIII.2021, always on the eastern side of the island. Bathing, free navigation, and free anchoring are allowed in zone C. Fortunately, most of the tourist flow is concentrated in the "coves", less frequented by C. panormitana panormitana.

\section{South-eastern Sicily}

In south-eastern Sicily, the locations already known in the bibliography have been confirmed.

It was not possible to verify the presence of this species in other suitable locations in both of these coasts and in other Sicilian locations.

The known bibliographic data and the present research are summarized in Fig. 3.

\section{DISCUSSION}

Calomera panormitana panormitana was considered for many years, especially in the first decades of 1900, to have disappeared from the Sicilian territory or at least to be in strong regression (Vitale, 1913). Cassola (1983), while confirming the presence of this species in several stations already known and reporting many new ones, underlined the ecological peculiarities of $C$. panormitana panormitana. It lives in small environments of rocky coast near the sea, restricted and isolated from each other, often due to the presence of anthropic alterations of the coast. Its populations are almost always composed by few speciemens.

This type of rocky coast is almost always characterized, along the tidal line, by the presence of a vermetid "trottoir". The vermetid trottoir (or rim, sidewalk) is a coastal carbonate platform, positioned between the sea and the rocky coast, formed as a result of a process of cementation of shells of some species of molluscs of the family of Vermetidae, in particular Dendropoma cristatum (Biondi, 1857) and Vermetus triquetrus Bivona-Bernardi, 1832. This biostructure, characteristic of the Mediterranean Sea and similar to coral reefs, plays an ecological role of great importance by promoting the settlement and development of numerous animal and plant species (Pandolfo et al., 1992; Chemello et al., 2000; Chemello, 2009; Gordó-Vilaseca et al., 2021).

Although C. panormitana panormitana does not live in this environment, the vermetid trottoir undoubtedly plays a key function in the habitat selection of this species (Fig. 6). The rocky coasts, in the presence of the vermetid trottoir, offer an environment less subject to the force of the waves and more sheltered from the sea, allowing this species to prey on, for example, also the populations of Ligia italica Fabricius, 1798, which are more numerous on the rocks touching the sea.

The population of $C$. panormitana panormitana found on the island of Levanzo in a stretch of coastline without vermetid trottoir stands several meters above the sea level and further back along the coastline compared to other stretches of coastline. For example, on the coast of Sferracavallo, characterized by a notable expansion of the vermetid trottoir, these populations reach the edge of the water. If disturbed, they fly off towards the sea only to return to a different place of the coast.

\section{CONCLUSIONS}

The study we have undertaken in recent years on the presence of C. panormitana panormitana in Sicily confirms, despite the reporting of several new locations, the concerns about the survival of this species.

The major risk factors are: the populations formed almost always by few specimens; the small and isolated environments; the period of biological activity of the adults which coincides with the summer months and therefore with a greater anthropic pressure on these locations, and the environmental alterations of the Sicilian coasts.

Probably, the excellent flying abilities of $C$. panormitana panormitana and life in the rocky coasts, less preferred by the human bathing activities than the sandy coasts, allow to this species higher chances of survival. The presence of $C$. panormitana panormitana in some small circumsicilian islands allows this species to have also important refuge areas, as in the case of Isola Lunga and Isola delle Femmine in particular, where it can survive better and recolonize the nearby coasts. 
Usually, tiger beetles are good bioindicators for habitat degradation (Cassola \& Pearson, 2000; Pearson \& Vogler, 2001; Aydin et al., 2005; Aydin, 2011). Calomera panormitana is an important Sicilian endemic threatened with extinction which needs a specific protection program in relation to the ecological and biological characteristics of this species and of the peculiar environments in which it lives.

\section{ACKNOWLEDGEMENTS}

We want to thank very much Camillo Cusimano e Gianandrea La Porta for his help in using QGis, Rocco Lo Duca for coming with us in our trip in the Aegadian Islands. We want to thank very much Vincenzo Di Dio, the director of the Reserve "Isola delle Femmine" (Palermo, Italy) who made it possible to collect the material for this study and facilitated all phases such as use of the boat to reach the island, sampling, etc. Activity carried out within the convention between the SAAF department and Lipu ("Check list delle specie di invertebrati, vertebrati ed individuazione delle migliori tecniche di propagazione del Lentisco (Pistacia lentiscus) presenti nell'Isola delle Femmine, Palermo", project head Tommaso La Mantia, Professor at the University of Palermo).

\section{REFERENCES}

Aliquò V. \& Castelli V.D., 1991. Nuovi dati sui coleotteri Cicindelidi e Carabidae del Trapanese. Libera Università Trapani, 10: 1-66.

Aliquò V. \& Romano F.P., 1975. Quinto contributo alla conoscenza della fauna coleotterologica della regione sicula (Cicindelidae, Carabidae). Bollettino romano d'entomologia, 30: 27-29.

Arnone M., 1994. Materiali per una catalogo della collezione Raniero Alliata. II. Coleoptera Cicindelidae. Il Naturalista siciliano, 18: 145-155.

Aydın G., 2011. Conservation status of the Tiger Beetle Calomera aphrodisia (Baudi di Selve, 1864) in Turkey (Coleoptera: Cicindelidae), Zoology in the Middle East, 52: 121-123. https://doi.org/10.1080/09397140. 2011.10638489

Aydın G., Şekeroğlu E. \& Arndt E., 2005. Tiger beetles as bioindicators of habitat degradation in the Çukurova Delta, southern Turkey. Zoology in the Middle East, 36: 51-58. https://doi.org/10.1080/ 09397140. 2005.10638127
Cassola F., 1982. Endemismi italiani. 22. Lophyridia aphrodisia panormitana (Ragusa) (Studi sui Cicindelidi. XXII). Bollettino dell'associazione romana di entomologia, 35 (1980).

Cassola F., 1983. Studi sui Cicindelidi. XXXII. Note e osservazioni su un interessante endemita siciliano: Lophyridia aphrodisia panormitana (Ragusa) (Coleóptera Cicindelidae). Il Naturalista siciliano, 7: 4156.

Cassola F. \& Pearson D.L., 2000. Global pattern of the tiger beetle species richness (Coleoptera: Cicindeli dae): Their use in conservation planning. Biological Conservation, 95: 197-208.

Chemello R., 2009. Le biocostruzioni marine in Mediterraneo. Lo stato delle conoscenze sui reef a vermeti. Biologia Marina Mediterranea, 16: 2-18

Chemello R., Dieli T. \& Antonioli F., 2000. Il ruolo dei "reef" a molluschi vermetidi nella valutazione della biodiversità in: Mare e cambiamenti globali. Aspetti scientifici e gestione del territorio, ICRAM, Roma, pp. 105-118.

Di Dio V., 2011. La Riserva Naturale Orientata Isola delle Femmine, pp. 25-29. In: AA.VV. (a cura di), L'educazione Ambientale per la sostenibilità dello sviluppo. Gazzetta Ambiente, 17(4).

Donato G., 2013. L'Isola che non c'era. Edizioni Danaus, Palermo, $128 \mathrm{pp}$.

Gordó-Vilaseca C., Templado J. \& Coll M., 2021. The Need for Protection of Mediterranean Vermetid Reefs., Reference Module in Earth Systems and Environmental Sciences, Elsevier. https://doi.org/10.1016/B978-0-12-821139-7.00102-1

Lapiana \& Sparacio, 2008. Lo studio degli Insetti nella valutazione della naturalità degli ambienti dunali costieri in Sicilia: Coleoptera e Orthoptera. Il Naturalista siciliano, 32: 411-434.

Lisa T., 2002. Le Cicindele d'Italia - Les Cicindèles d'Italie (Coleoptera, Adephaga, Cicindelidae). Revue de l'Association Roussillonnaise d'Entomologie, supplément au Tome 11, 55 pp.

Pandolfo A., Chemello R. \& Riggio S., 1992. Notes sur la signification écologique de la malacofaune d'un "Trottoir à Vermets" le long de la côte de Palerme (Sicile). Rapports et procés-verbaux des réunions Commission internationale pour l'exploration scientifique de la Mer Méditerranée, 33, 47.

Pearson D.L. \& Vogler A.P., 2001. Tiger Beetles: the evo lution, ecology and diversity of the cicindelids. Ithaca \& London, $333 \mathrm{pp}$.

Ragusa E., 1882. Coleotteri nuovi o poco conosciuti di Sicilia. Il Naturalista siciliano, 1: 5-9.

Ragusa E., 1884. Coleotteri nuovi o poco conosciuti di Sicilia. Il Naturalista siciliano, 3: 316-318.

Ragusa E., 1887. Coleotteri nuovi o poco conosciuti di Sicilia. Il Naturalista siciliano, 6: 214-216. 
Ragusa E., 1904. Coleotteri nuovi o poco conosciuti di Sicilia. Il Naturalista siciliano, 17: 84.

Ragusa E., 1906. Coleotteri nuovi o poco conosciuti di Sicilia. Il Naturalista siciliano, 18: 247-250.

Ragusa E., 1921. Coleotteri nuovi o poco conosciuti di Sicilia. Bollettino della Società entomologica italiana, 53: 31-36.

Romano M. \& Sparacio I., 2018. Taxonomic and biogeographical observations on a new population of Calomera Motschulsky, 1862 (Coleoptera Carabidae Cicindelinae) from Crete Island (Greece). Biodiversity Journal, 9: 195-204.

Sparacio I., 1994. Coleotteri di Sicilia, I. L'Epos, Palermo, $260 \mathrm{pp}$.

Sturani, 1981. Osservazioni ecologiche e biologiche su una interessante stazione di Cephalota (Taenidia) li- torea goudoti (Dejean) in Sicilia (Coleoptetra Cicindelidae). Rivista piemontese di Storia Naturale, 2: 55-58.

Surdo S., 2016. Osservazioni di Cephalota circumdata imperialis (Klug, 1834) (Insecta Carabidae Cicindelinae) in Sicilia. Il Naturalista siciliano, 40: 319321.

Vitale F., 1912. Catalogo dei Coleotteri di Sicilia. Adephaga: Cicindelidae. Rivista coleotterologica italiana, 10: 41-50.

Vitale F., 1913. La Cicindela panormitana Rag. et sa prochain disparition. L'Echange, 29: 180-181.

Vitale F., 1927. Coleotteri nuovi o poco conosciuti di Sicilia. Memorie della Società entomologica italiana, 6: 44-54. 